\title{
Методологічні підходи оцінки зон трансферу кукурудзи на зерно за показником урожайності
}

\author{
В.М. Тимчук' ${ }^{1}$ Н.Ю. Єгорова², Є.С. Бондаренко ${ }^{3}$, \\ Л.С. Осіпова ${ }^{4}$, С.Ф. Халін ${ }^{5}$ \\ 1,2,3 /нститут рослинництва ім. В. Я. Юр'єва НААН (м. Харків, Україна) \\ 4,5 Луганський національний аграрний університет (м. Харків, Україна) \\ 4 ludmila.cattleya@gmail.com, ${ }^{5}$ Khalin_sergey@ukr.net \\ ORCID: ${ }^{1}$ 0000-0002-3742-2229,
}

email: ${ }^{1}$ syrgis@gmail.com, ${ }^{2}$ yuriev1908marketing@gmail.com, 3 yuriev1908centre@gmail.com

\begin{abstract}
В якості специфічних зон трансферу кукурудзи на зерно аналізували 25 областей та загальний рівень по Україні. Аналіз проводили за показником урожайності впродовж 2000-2016 pp. За коефріцієнтом регресії всі області характеризувалися позитивним значенням в межах 0,03-0,58. Для більш системного врахування зональних особливостей аналізували середній $(\bar{x})$ та мінімальний (min) і максимальний (max) рівень показників в абсолютному та порівняно до України форматах. Додатково аналізували статистичні та регресійні коефіцієнти як індикатори рівня та характеру наявних процесів. По кожній з градацій за рахунок ранжування виділяли типові пули областей 3 формалізованою типовістю за технологічним забезпеченням та реалізацією генетичного потенціалу продуктивності (РГПП). За точністю апроксимації (R2) при виділеному рівні 0,8 (задовільна апроксимація) виділялися АРК*, Волинська, Івано-Франківська, Рівненська, Сумська, Тернопільська та Херсонська області, в яких в ближній перспективі можна очікувати зростання урожайності кукурудзи на зерно. Формалізовано частка суми всіх градацій урожайності кукурудзи на зерно $\leq 5,0$ т/га становить $66,6 \%$ та $\geq 5,0$ т/га 33,4\%. За показником урожайності провідний сегмент (76\%) сорормували 12 областей (48\%) з коефіцієнтом варіації $\bigvee \%$ - 20\% та 7 областей (28\%) V\% $30 \%$. Проведений аналіз виділив актуальність зональної спеціалізації та розробки і запровадження системи поправочних коефіцієнтів для досягнення репрезентативного та одно фрорматного коректного рівня порівняння зон трансфреру. При цьому показник урожайності розглядається як індикатор необхідності обґрунтованого корегування або розробки зональної системи технологічного забезпечення виробництва кукурудзи на зерно.
\end{abstract}

Ключові слова: кукурудза на зерно, зони трансферу, урожайність, варіація.

\begin{abstract}
Аналіз останніх досліджень та публікацій. В сучасних ринкових умовах рівень зональної спеціалізації системно стає індикатором ефективності функціонування галузі рослинництва, грамотного використання біологічних особливостей культур та ґрунтово-кліматичних умов зон вирощування як додаткових конкурентних переваг [1, 2]. Для аргументованого і зваженого вибору ефективних зон трансферу менеджери, аналітики, оригінатори та інвестори мають керуватися дієвою системою метрик як складових технологій $[2,3]$. Серед основних показників, на базі яких на теперішній час оцінюються і обираються зони трансферу, в першу чергу використовують статистичні: посівні (збиральні) площі, валові збори та урожайність [4]. При цьому, як правило, оцінку проводять за одним 3 наведених вище показників у відриві від інших та без застосування системного підходу. Водночас, в динамічних умовах кліматичних і економічних трансформацій та діючої стихійної зональної спеціалізації в значній мірі діють внутрішні і зовнішні механізми та закономірності, встанов-
\end{abstract}

лення яких має практичну значимість з позицій ефрективної реалізації комплексу конкурентних переваг $[5,6]$. Все означене вище досить чітко вписується до генерального вектору переходу до рівня трансферу цілісних технологій та інноваційного розвитку АПВ України $[7,8]$.

Постановка проблеми. В сучасних ринкових умовах рівень зональної спеціалізації все більше стає чітким індикатором ефективності i грамотного використання біологічних особливостей культур та ґрунтово-кліматичних умов зон вирощування як додаткових конкурентних переваг. При переході виробництва на вектори стандартизованих сировинних ресурсів (ССР) та оптимізованої логістики маржинальність виробництва напряму залежить від аргументованої зональної та сировинної спеціалізації. Для аргументованого і зваженого вибору ефективних зон трансферу та системи технологічного забезпечення менеджери, аналітики, оригінатори ОПІВ та інвестори мають керуватися дієвою системою метрик та аналітики. Серед основних показників, на базі яких на теперішній час оцінюються і 
обираються зони трансферу, в першу чергу використовують статистичні: посівні (зібрані) площі, валові збори та урожайність. При цьому, як правило, оцінку проводять за одним 3 наведених вище показників у відриві від інших та без застосування системного підходу. Між тим в динамічних умовах кліматичних трансформацій та стихійної зональної спеціалізації в значній мірі діють внутрішні і зовнішні механізми та закономірності, встановлення яких має практичну значимість з позицій ефективної реалізації комплексу конкурентних переваг.

Мета і завдання дослідження. Розробити методологічні підходи оцінки і вибору зон трансферу кукурудзи на зерно в системі стандартизованих сировинних ресурсів і трансферу цілісних технологій на рівні областей Україні.

Матеріали і методика. Дослідження проводили згідно завдань тематичного плану Інституту рослинництва ім. В.Я. Юр'єва НААН впродовж 2011-2017 рр. Предметом досліджень було визначено зони вирощування кукурудзи на зерно в системі трансферу цілісних технологій. При розробці робочих моделей виходили 3 наявного статусу та перспектив, структурної та ієрархічної побудови систем, формалізації та системного підходу на засадах наскрізної координації. В процесі статистичного аналізу використовували абсолютні та відносні показники, динамічних та структурних змін, статистичні методи аналізу і прогнозування, табличний і графічний методи представлення результатів.

Результати досліджень. 3 позицій ефективного та конкурентоздатного виробництва на передній край системно виходять питання ефективного використання задіяних ресурсів, особливо земельних, агрокліматичних та технологічних. 3 позицій. оцінки цього блоку дієвим показником виступають урожайність та реалізація генетичного потенціалу продуктивності (ГПП). 3 іншого боку саме за рахунок оптимального рівня урожайності досягається висока маржинальність та конкурентоздатність. Тому показник урожайності по кукурудзі на зерно на рівні областей цілком прагматично можна розглядати як індикатор агрокультури, збалансованість зональної специфіки і необхідний рівень компенсаторики задіяних технології, параметри і підходи коректної оцінки в системі зональної спеціалізації та трансферу в галузі рослинництва. Слід також зазначити, що урожайність враховує основні керовані фрактори трансферного процесу на противагу виробництву та посівним площам. Відносно кукурудзи на зерно стратегічним рівнем середньої багаторічної врожайності $€ \geq 5,0$ т/га. Що зумовлює сталий характер іï̈ нарощування і зменшення різниці між мінімальними (min) та середніми $(\bar{x})$ рівнями показника. Одночасно з цим різниця між середнім ( $\bar{x})$ та максимальним (max) рівнями урожайності має бути наближеною до модельно обґрунтованого рівня РГПП -70\%. При цьому 3 методологічної точки зору цілком обґрунтованою $€$ оцінка з урахуванням всіх наявних і потенційних градацій. Одним з таких найбільш адаптованих до ординарного сприйняття підходів $\epsilon$ рангова оцінка. 3 цього огляду було проведено рангову оцінку областей України в період 2000-2016 рр. за показником урожайності кукурудзи на зерно (табл.1).

На відміну від показників валових зборів та посівних площ розмах мінливості за показником урожайності по вибірці був значно меншим. (1,06 - 9,11 т/га), що в значній мірі пов'язано з характером кукурудзи на зерно як біологічного об'єкту 3 достатньо регламентованим рівнем продуктивності на рівні гібридів. Одночасно з цим рівень задіяних технологій та ресурсів $є$ достатньо регламентованим. При цьому слід ще раз слід підкреслити, що показник урожайності є найбільш керованим і представляє значний інтерес саме 3 позицій організації трансферного процесу.

При ранжуванні областей за градацією мінімальної урожайності кукурудзи на зерно (min) перша п'ятірка областей включала: Львівську - 1, Чернівецьку - 2, Чернігівську - 3, Київську - 4 та Закарпатську - 5 області. За градацією середньої урожайності ( $\bar{x})$ перша п'ятірка областей охоплювала Черкаську - 1, Київську - 2, Житомирську - 3, $\mathrm{APK}^{*}$ - 4 та Хмельницьку області, а за показником максимальної урожайності (max) - Черкаську - 1, АПК ${ }^{*}$ - 2, Вінницьку - 3, Сумську - 4 та Рівненську - 5 області. Тобто, наявними $€$ специфічні зональні особливості, які мають бути враховані при оцінці і виборі зон трансферу. Що підтверджує аргументованість і коректність обраного напряму.

При аналізі і прогнозуванні фактору урожайності як і по показниках валових зборів та посівних площ обов'язковим $є$ врахування показників коефіцієнтів регресії (b), детермінації $\left(R^{2}\right)$ та варіації (V\%).

За коефіцієнтом регресії всі області характеризувалися позитивним значенням в межах 0,030,58, що не свідчить про активне нарощування рівня урожайності в ближній перспективі. Що підтверджується позитивною динамікою нарощування показника середньої урожайності кукурудзи на зерно $(\overline{\mathrm{x}})$ в областях України. Практично всі області характеризувалися позитивним трендом, що свідчить про позитивні зміни у рівнях:

а) селекції і насінництва;

б) технологічного забезпечення за складовими;

в) змін внаслідок кліматичних трансформацій;

г) змін у статусі кукурудзи як експортного об'єкта;

д) змін у статусі кукурудзи за зерно як ефективного об'єкта трансферу. 
В.М. Тимчук, Н.Ю. Єгорова, Є.С. Бондаренко, Л.С. Осіпова С.Ф. Халін

V.M. Tymchuk, N.Yu. Yehorova, Ye.S. Bondarenko, L.S. Osipova, S.F. Halin

Таблиця1. Рангова оцінка областей України за показником урожайності кукурудзи на зерно 2000-2016 рр., т/га

\begin{tabular}{|c|c|c|c|c|c|c|c|c|c|c|c|c|c|c|c|}
\hline \multirow[t]{2}{*}{ № } & \multirow[t]{2}{*}{ Області } & \multicolumn{9}{|c|}{ Урожайність т/га } & \multicolumn{3}{|c|}{$\begin{array}{c}\text { Статистичні та } \\
\text { регресійні } \\
\text { коефріцієнти }\end{array}$} & \multirow{2}{*}{$\begin{array}{c}\text { Сума } \\
\text { рангі } \\
\text { в }\end{array}$} & \multirow{2}{*}{$\begin{array}{c}\text { Сукуп- } \\
\text { ний } \\
\text { ранг }\end{array}$} \\
\hline & & $\min$ & $\begin{array}{c} \pm \text { до } \\
\text { України }\end{array}$ & Ранг & $\max$ & $\begin{array}{c} \pm \text { до } \\
\text { України }\end{array}$ & Ранг & $\overline{\mathrm{x}}$ & $\begin{array}{c} \pm \text { до } \\
\text { України }\end{array}$ & Ранг & V\% & $\mathrm{R}^{2}$ & $\mathrm{~b}$ & & \\
\hline 1 & APK $^{*}$ & 1,44 & $-1,35$ & 21 & 8,92 & $+2,24$ & 2 & 5,71 & $+1,04$ & 4 & 47.7 & 0,80 & 0,58 & 27 & 8 \\
\hline 2 & Вінницька & 3,55 & $+0,76$ & 8 & 8,47 & $+1,79$ & 3 & 5,54 & $+0,87$ & 6 & 30,1 & 0,64 & 0,26 & 17 & 3 \\
\hline 3 & Волинська & 3,02 & $+0,23$ & 11 & 7,75 & $+1,07$ & 10 & 5,48 & $+0,81$ & 8 & 30,6 & 0,86 & 0,31 & 29 & 9 \\
\hline 4 & Дніпропетровська & 1,73 & $-1,06$ & 19 & 4,50 & $-2,18$ & 21 & 3,20 & $-1,47$ & 21 & 20,8 & 0,01 & 0,02 & 61 & 19 \\
\hline 5 & Донецька & 1,38 & $-1,41$ & 22 & 3,76 & $-2,92$ & 22 & 2,91 & $-1,76$ & 23 & 20,7 & 0,05 & 0,03 & 67 & 20 \\
\hline 6 & Житомирська & 3,07 & $+0,28$ & 12 & 8,11 & $+1,43$ & 7 & 5,86 & $+1,19$ & 3 & 27,9 & 0,56 & 0,24 & 22 & 5 \\
\hline 7 & Закарпатська & 3,76 & $+0,97$ & 5 & 5,47 & $-1,21$ & 18 & 4,51 & $-0,16$ & 17 & 9,1 & 0,29 & 0,04 & 40 & 14 \\
\hline 8 & Запорізька & 1,06 & $-1,73$ & 24 & 3,28 & $-3,40$ & 24 & 2,44 & $-2,23$ & 25 & 30,9 & 0,34 & 0,09 & 73 & 22 \\
\hline 9 & Івано-Франківська & 3,13 & $+0,34$ & 10 & 7,15 & $+0,47$ & 13 & 4,90 & $+0,23$ & 15 & 25,6 & 0,87 & 0,23 & 38 & 13 \\
\hline 10 & Київська & 3,92 & $+1,13$ & 4 & 8,04 & $+1,36$ & 8 & 5,99 & $+1,23$ & 2 & 20,8 & 0,69 & 0,20 & 14 & 2 \\
\hline 11 & Кіровоградська & 3,13 & $+0,34$ & 10 & 6,56 & $-0,12$ & 16 & 4,37 & $-0,30$ & 18 & 25,0 & 0,52 & 0,16 & 44 & 15 \\
\hline 12 & Луганська & 1,32 & $-1,47$ & 23 & 3,54 & $-3,14$ & 23 & 2,65 & $-2,02$ & 24 & 29,4 & 0,75 & 0,09 & 70 & 21 \\
\hline 13 & Львівська & 4,20 & $+1,41$ & 1 & 7,01 & $+0,33$ & 14 & 5,51 & $+0,84$ & 7 & 17,1 & 0,66 & 0,15 & 22 & 6 \\
\hline 14 & Миколаївська & 1,53 & $-1,26$ & 20 & 4,66 & $-2,02$ & 20 & 3,24 & $-1,43$ & 20 & 30,7 & 0,32 & 0,11 & 60 & 18 \\
\hline 15 & Одеська & 2,08 & $-0,71$ & 18 & 4,75 & $-1,93$ & 19 & 2,98 & $-1,69$ & 22 & 55,3 & 0,06 & 0,09 & 59 & 17 \\
\hline 16 & Полтавська & 2,81 & $+0,02$ & 14 & 7,89 & $+1,21$ & 9 & 5,13 & $+0,46$ & 12 & 30,9 & 0,74 & 0,27 & 35 & 12 \\
\hline 17 & Рівненська & 3,25 & $+0,46$ & 9 & 8,26 & $+1,58$ & 5 & 5,36 & $+0,69$ & 10 & 33,6 & 0,81 & 0,32 & 24 & 7 \\
\hline 18 & Сумська & 2,40 & $-0,39$ & 17 & 8,32 & $+1,67$ & 4 & 4,96 & $+0,29$ & 13 & 40,5 & 0,85 & 0,37 & 34 & 11 \\
\hline 19 & Тернопільська & 2,94 & $+0,15$ & 13 & 7,75 & $+1,07$ & 10 & 5,18 & $+0,51$ & 11 & 31,7 & 0,88 & 0,30 & 34 & 11 \\
\hline 20 & Харківська & 2,57 & $-0,22$ & 15 & 5,66 & $-1,02$ & 11 & 3,86 & $-0,81$ & 19 & 28.6 & 0,63 & 0,17 & 44 & 15 \\
\hline 21 & Херсонська & 2,46 & $-0,33$ & 16 & 6,50 & $-0,18$ & 15 & 4,56 & $-0,11$ & 16 & 29,2 & 0,81 & 0,24 & 47 & 16 \\
\hline 22 & Хмельницька & 3,62 & $+0,83$ & 7 & 8,24 & $+1,56$ & 6 & 5,58 & $+0,91$ & 5 & 24,4 & 0,69 & 0,22 & 18 & 4 \\
\hline 23 & Черкаська & 3,72 & $+0,93$ & 6 & 9,11 & $+2,43$ & 1 & 5,92 & $+1,25$ & 1 & 25,1 & 0,68 & 0,24 & 8 & 1 \\
\hline 24 & Чернівецька & 3,95 & $+1,16$ & 2 & 6,34 & $-0,34$ & 17 & 4,91 & $+0,24$ & 14 & 13,9 & 0,56 & 0,10 & 33 & 10 \\
\hline 25 & Чернігівська & 3,94 & $+1,15$ & 3 & 7,20 & $+0,52$ & 12 & 5,42 & $+0,75$ & 9 & 22,4 & 0,73 & 0,20 & 24 & 7 \\
\hline 26 & Україна & 2,79 & & & 6,68 & & & 4,67 & & & 37.1 & 0.84 & 0.22 & & \\
\hline
\end{tabular}

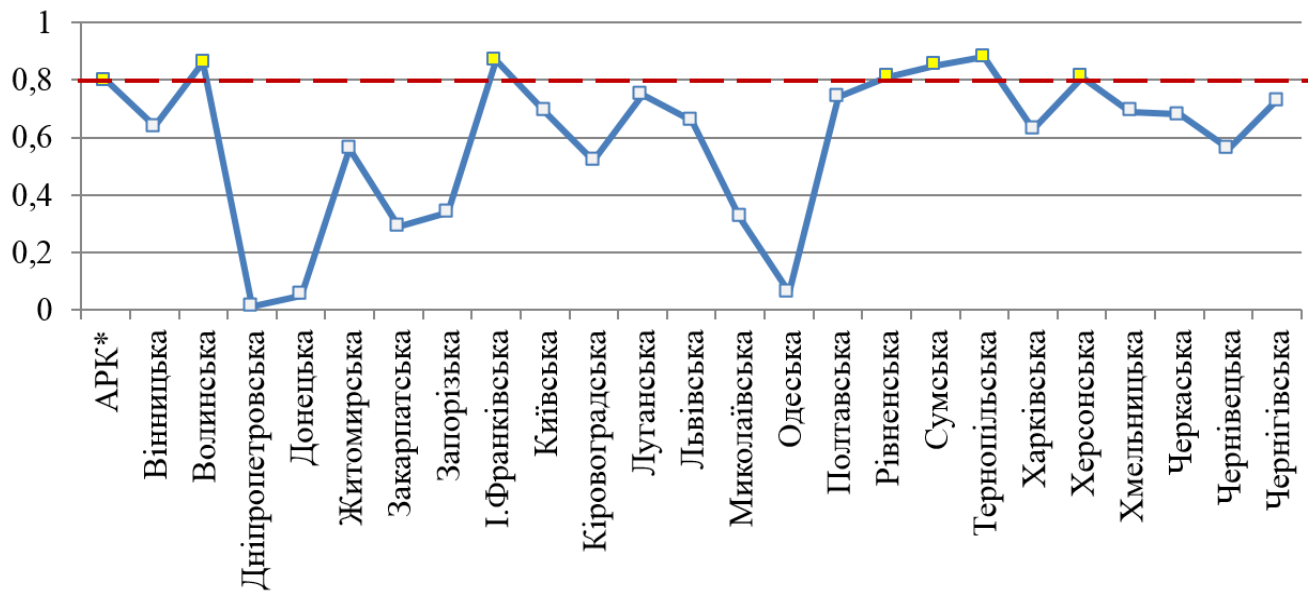

Рис.1. Аналіз очікуваності нарощування урожайності кукурудзи на зерно в областях України, за точністю коефіцієнту регресії $\left(R^{2}\right)$ в ближній перспективі, середнє 2000-2016 pp.

*Без врахування тимчасово окупованих територій АРК з 2014 p.

Враховуючи діючу статистику, слід зазначити наявний розподіл областей на донорів зростання рівня урожайності в Україні та області з показниками нижчими за рівень урожайності в Україні. Тобто, при оцінці областей як специфічних зон трансферу це слід враховувати задля коректності порівняння, а також при формуванні відповідних програм зональної спеціалізації.

За точністю апроксимації $\left(R^{2}\right)$ при виділеному рівні 0,8 (задовільна апроксимація) виділялися 
АРК*, Волинська, Івано-Франківська, Рівненська, Сумська, Тернопільська та Херсонська області, в яких в ближній перспективі можна очікувати зростання урожайності кукурудзи на зерно (рис.1).Як було зазначено вище, для проведення більш уточненого аналізу при оцінці областей як зон трансферу прагматично цікавим $\epsilon$ характер співвідношення між мінімальними (min), середніми $(\overline{\mathrm{x}})$ та максимальними $(\max )$ градаціями реалізації показника урожайності кукурудзи на зерно (табл. 2).

При такому підході досить оперативно та репрезентативно можна виділяти і порівнювати об- ласті між собою та з рівнем України. Тому виділений алгоритм та підходи графічного моделювання становлять інтерес, в тому числі і як структурована блок-схема /електронна форма організації спеціалізованих аналітично прогнозних баз за рівнями і напрямами трансферу. Модельно відносно емпірично виділеного рівня урожайності кукурудзи на зерно 5,0 т/га отримано підтвердження коректності розрахунків.

Так ,по таблиці видно, що лінія розподілу на нижню ліву і верхню праву частини 3 датами максимальної урожайності (max) досить модельно розподіляються саме на рівні наближеної до 5,0 т/га.

Таблиця 2. Розподіл рівнів посівних площ по кукурудзі на зерно в областях України, 2010 - 2016 рр., тис. Га

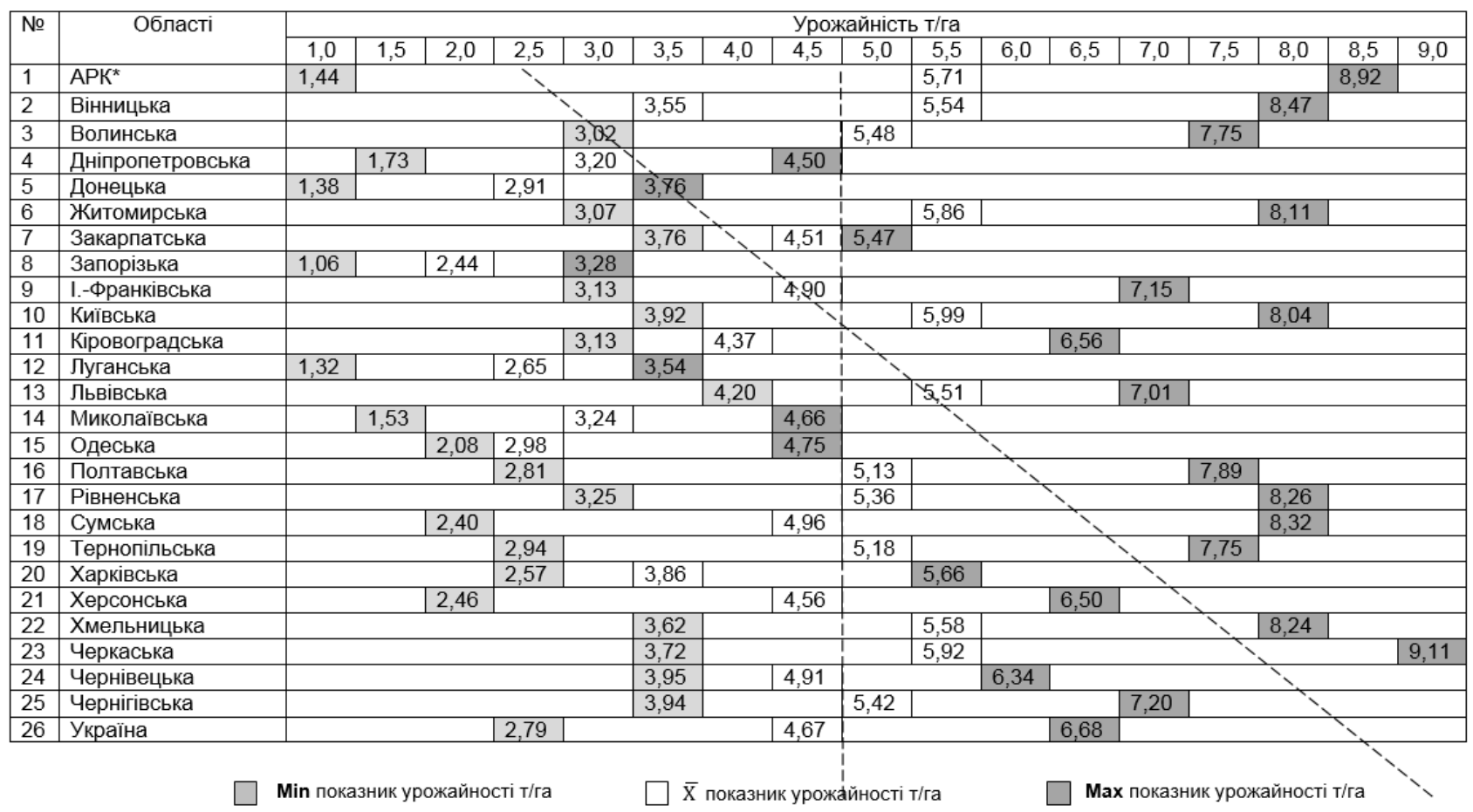

При цьому якщо поділити блок-схему по діагоналі починаючи з рівня мінімальної урожайності по Україні (min) 2,79 т/га - переважна кількість дат на рівні областей і градацій локалізована в сегменті рівня урожайності. $\leq 5,0$ т/га. В верхньому ж правому сегменті локалізовані дати на максимальному рівні (max). Якщо більш детально проаналізувати, то в ближній перспективі стратегічний рівень урожайності кукурудзи на зерно має бути скорегований до рівня 6,5 т/га.

Так, формалізовано частка суми всіх градацій урожайності кукурудзи на зерно (25 областей + Україна - всього 78 дат) становить включно до стратегічного рівня урожайності 5,0 т/га - 66,6\% - (лівий нижній сегмент), а вище стратегічного рівня (правий верхній сегмент) $-33,4 \%$ (рис. 2 ).

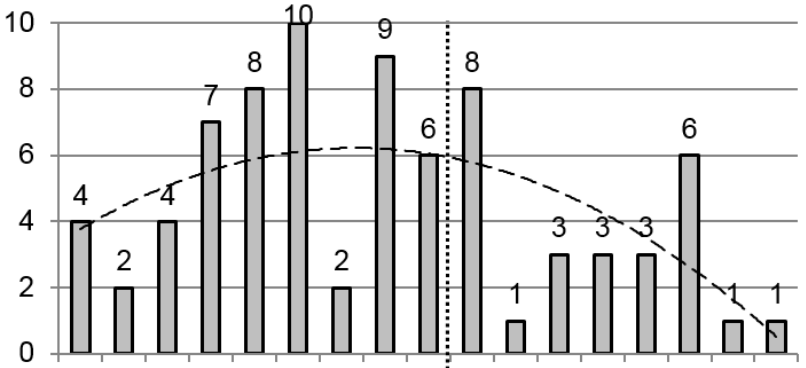

$\begin{array}{llllllll:llllllll}1 & 1,5 & 2 & 2,5 & 3 & 3,5 & 4 & 4,5 & 5 & 5,5 & 6 & 6,5 & 7 & 7,5 & 8 & 8,5\end{array}$ $66.6 \%$

$33,4 \%$

Рис. 2. Модельний розподіл суми градацій урожайності кукурудзи на зерно в областях України, 2000-2016 рр., дат (до табл. 2). 
В разі корегування стратегічного рівня урожайності кукурудзи на зерно до 6,5 т/га за теперішнього проаналізованого рівня це співвідношення становить 82 : 18\% відповідно. Що індикативно виділяє необхідність переходу на нові технології та організаційні схеми. 3 методологічної точки зору такий підхід модельно виділяє основні першочергові вектори на рівні конкретних урожайностей та областей як складових трансферу.

Тому оцінка та виділення провідних зон трансферу на рівні областей кукурудзи на зерно як об'єкта трансферу має спиратися на відповідні методологічні підходи. Паралельно з цим виділений підхід при відповідній формалізації прагматично дає можливість розширення інструментарію методологічного забезпечення напрямів трансферу в галузі рослинництва.

Відносно показника урожайності кукурудзи на зерно суттєвим $€$ те, що рівень середньої урожайності $(\overline{\mathrm{x}})$ по областях умовно $€$ досить близьким (рис. 3).

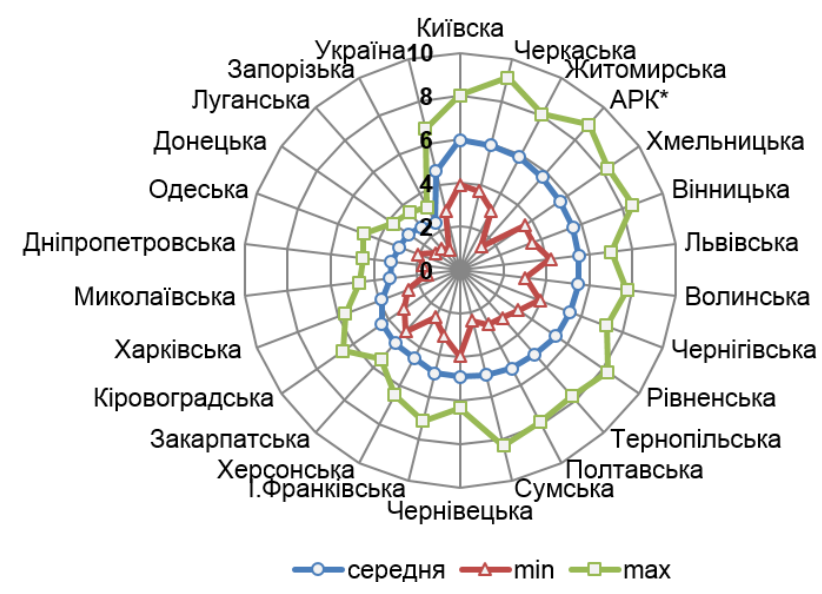

Рис. 3. Розподіл областей України за рівнями урожайності кукурудзи на зерно, середнє за 2000-2016 рр., т/га.

Приблизно подібним образом формалізовано може бути описаний і рівень максимальної урожайності (max). В той же час на рівні мінімальних урожайностей (min) такого чіткого розподілу не виділено.

Приблизно подібним образом фрормалізовано може бути описаний і рівень максимальної урожайності (max). В той же час на рівні мінімальних урожайностей (min) такого чіткого розподілу не виділено. Для ряду областей простежується більш низький рівень по всіх градаціях порівняно 3 провідними. 3 іншого боку різниця між градаціями мінімальної (min) і середньої $(\bar{x})$ урожайності $€$ нижчою ніж між середньої $(\bar{x})$ і максимальної (max) урожайності. Що можна розглядати як опосередковане свідчення значної вичерпності задіяних на теперішній час складових технологій вирощування кукурудзи на зерно і стратегічної необхідності переходу на новий технологічний рівень. Іншими словами подолання різниці між мінімальним (min) і середнім $(\bar{x})$ рівнями $€$ менш затратним і простішим ніж між середнім $(\bar{x})$ і максимальним (max) рівнями. Повертаючись до табл. 2 це досить системно підводить до обґрунтованого переходу до цілісних технологічних рішень, конвергентних технологій, зональної спеціалізації та точного землеробства. Тобто, в цьому сенсі рішення таких масштабних завдань має системно спиратися на необхідний рівень методологічного забезпечення та аналітики.

3 позицій оцінки та виділення стабільних за урожайністю зон трансферу кукурудзи на зерно за коефіцієнтом варіації V\% було проаналізовано розподіл та групування областей України за 2000-2016 рр. (табл. 3.).

Таблиця 3. Розподіл та групування областей України за стабільністю урожайності кукурудзи на зерно, 2000-2016 рр., за коефріцієнтом варіації V\%.

\begin{tabular}{|c|c|c|c|}
\hline 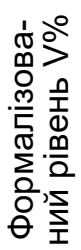 & 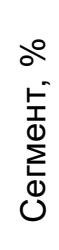 & Області & $\begin{array}{l}\stackrel{0}{>} \\
\stackrel{5}{5} \\
\frac{1}{5} \\
\frac{5}{5} \\
\frac{5}{0} \\
\theta \\
\theta\end{array}$ \\
\hline \multirow{3}{*}{10} & \multirow{3}{*}{12} & Закарпатська & 9,1 \\
\hline & & Чернівецька & 13,9 \\
\hline & & Львівська & 17,1 \\
\hline \multirow{12}{*}{20} & \multirow{12}{*}{48} & Донецька & 20,7 \\
\hline & & Дніпропетровська & 20,8 \\
\hline & & Чернігівська & 22,4 \\
\hline & & Хмельницька & 24,4 \\
\hline & & Київська & 20,8 \\
\hline & & Кіровоградська & 25,0 \\
\hline & & Черкаська & 25,1 \\
\hline & & Івано-Франківська & 25,6 \\
\hline & & Житомирська & 27,9 \\
\hline & & Харківська & 28,6 \\
\hline & & Херсонська & 29,2 \\
\hline & & Луганська & 29,4 \\
\hline \multirow{7}{*}{30} & \multirow{7}{*}{28} & Вінницька & 30,1 \\
\hline & & Волинська & 30,6 \\
\hline & & Миколаївська & 30,7 \\
\hline & & Запорізька & 30,9 \\
\hline & & Полтавська & 30,9 \\
\hline & & Тернопільська & 31,7 \\
\hline & & Рівненська & 33,6 \\
\hline \multirow{2}{*}{40} & \multirow{2}{*}{8} & Сумська & 40,5 \\
\hline & & $\mathrm{APK}^{*}$ & 47,7 \\
\hline 50 & 4 & Одеська & 55,3 \\
\hline
\end{tabular}


Слід зазначити, що поряд з областями зі стабільною урожайністю кукурудзи на зерно були області з більш високою варіабельністю цього показника. При цьому порівняно до показників валових зборів та посівних площ стабільність реалізації показника урожайності кукурудзи на зерно характеризувалася значно більшою стабільністю. Так провідний сегмент сформували 12 областей (48\% від проаналізованих) 3 формалізованим рівнем коефіцієнту варіації V\% $20 \%$, а в сумі з сегментом $\vee \%$ - $30 \%$ (7 областей $28 \%$ від проаналізованих) сукупний сегмент становив $76 \%$. Тобто, отримано підтвердження наявності достатньо високого рівня керованості реалізацією показника урожайності на теперішньому рівні технологічного забезпечення. При цьому слід зазначити, що реалізація генетичного потенціалу продуктивності (РГПП) на рівні 70\% це зовсім інший і більш високий рівень, який потребує відповідного технологічного та методологічного забезпечення. 3 позицій трансферу цілісних технологій та реалізації комплексу конкурентних переваг фрактор урожайності виділяється як найбільш активний і динамічний. Урожайність постає як системна реалізація комплексу конкурентних переваг через РГПП. 3 цього огляду аналіз фрактору урожайності потребує більш системного підходу.

За результатами проведеного аналізу отримано підтвердження, що в системі оцінки зон трансферу за ранговою оцінкою більш прагматичним $є$ врахування максимально більшої кількості фракторів, а орієнтація тільки на один фрактор не відбиває реальну картину.

Важливою складовою, яка є найбільш інтегрованою в систему трансферу, $є$ рівень виробництва, яке в свою чергу базується на фракторах урожайності та посівних площ. При цьому для коректної оцінки областей за виробництвом як зон трансферу слід спиратися на їх відповідне групування за зональним принципом, логістикою, інтеграцією в переробну промисловість та інше. При цьому на рівні областей важливе місце належить агрокліматичним умовам та організаційно-технологічним фракторам, які мають бути системно спрямовані на сталу ефективну РГПП, економіку та якість продукції за напрямами ССР.

У проведених дослідженнях було виділено орієнтацію на ефективне використання всіх наявних ресурсів - тому застосування рангової оцінки $\epsilon$ обґрунтованим і виправданим. 3 позицій оцінки ефективності виробництва одним з показників виділяється його стабільність. Виділені підходи 3 використанням правила Паретто можуть розглядатися як цілком обґрунтований інструментарій при запровадженні зональної концентрації та спеціалізації виробництва з урахування відповідної логістики та вимог біології культури.
Важливим показником щодо оцінки рівня привабливості областей як зон трансферу виділяється рівень рентабельності виробництва кукурудзи на зерно (рис. 4).

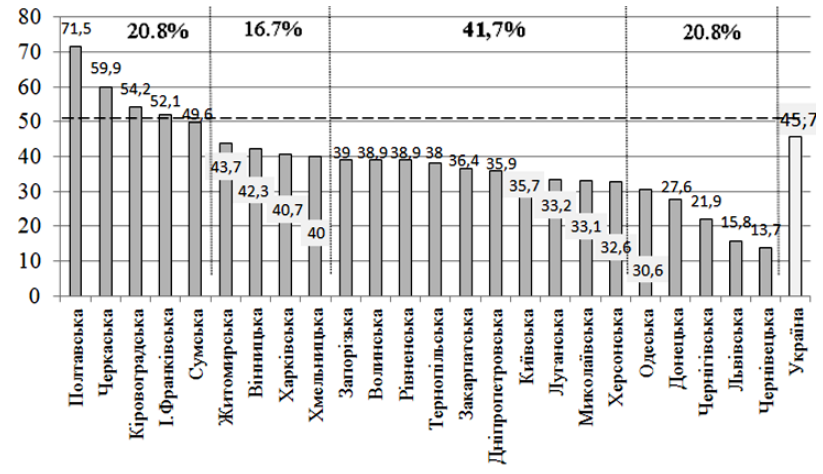

Рис. 4. Аналіз групування областей України за рівнем рентабельності виробництва кукурудзи на зерно (розраховано за даними Держкомстату України, 2016 р.).

При середньому показнику по Україні 45,7\% тільки 5 областей (Полтавська, Черкаська, Кіровоградська, І.Франківська та Сумська - 20,8\% від проаналізованих) мали рентабельність вищу за рівень України. Саме цей сегмент і є основним донором у формуванні загальнодержавного рівня рентабельності по кукурудзі. Наступний сегмент умовно наближений до рівня України склали 4 області (Житомирська, Вінницька, Харківська та Хмельницька - 16,7\% від проаналізованих) мали рентабельність меншу за рівень України в межах $5 \%$. Основний сегмент склали 10 областей (Запорізька, Волинська, Рівненська, Тернопільська, Закарпатська, Дніпропетровська, Київська, Луганська, Миколаївська та Херсонська - 41,7\% від проаналізованих).

Перший сегмент з найнижчою рентабельністю виробництва кукурудзи на зерно сфрормували 5 областей (Одеська, Донецька, Львівська, Чернівецька та Чернігівська - 20,8\% від проаналізованих). Два останніх сегменти є чистими акцепторами і потребують поглибленого аналізу та оптимізації. В цьому плані цілком логічним виділяється розробка та запровадження системи поправочних коефіцієнтів для більш точної формалізованої оцінки зон трансферу за економічними показниками. Середній рівень витрат на 1 ц основної продукції по кукурудзі на зерно становить по Україні 197,5 грн (для порівняння соняшнику 448,3 грн та пшениці озимій 220,9 грн), що виділяє її як достатньо маржинально привабливу культуру. Тобто при оцінці кукурудзи як об'єкта трансферу слід комплексно враховувати її показники за принципом SWOT аналізу. 
Висновки. При оцінці зон трансферу кукурудзи на зерно за показником посівних площ на рівні областей України слід оперувати розширеним набором фракторів та поглибленим системним аналізом. Розгляд культур як специфрічних об'єктів трансферу, а областей як зон трансферу виділяє підвищену актуальність відповідного методологічного супроводження. При цьому значні перспективи проглядаються у створенні аналітично-прогнозних баз, при оперуванні якими $€$ реальна можливість комерційного супроводження зональної спеціалізації та корегування галузевих регіональних програм.

\section{Література}

1. Кропивко В. Продовольча безпека країни: стан та перспективи / Валентина Кропивко // Матеріали інтернет-конференції 20-21 жовтня 2011 р. Тернопільський інститут АПВ НААН - секція 5. Економічні науки. [Електронний ресурс]. Режим доступу: http://www.conftiapv.at.ua/publ/konf_20_2 1_zhovtnja_2011_r/sekcija_5_ekonomichni_naukī/.. $. / 23-1-0-11 \overline{2} 3$

2. Тимчук В. М. Проблемні питання трансферу технологічних інновацій в АПВ. Вісник аграрної науки. № 2, 2013. - С.23-25.

3. Матюшенко І. Ю. Технологічна конкурентоспроможність України в умовах нової промислової революції і розвитку конвергентних технологій. Проблеми економіки. 2016. № 1. С. 108-120.

4. Державна служба статистики України. Офрiційний сайт. [Електронний ресурс]. Режим доступу: http://www.ukrstat.gov.ua

5. Трибель С. О., Ретьман С. В., Борзих О. І., Стригун О. О. Стратегічні культури. За ред. С. О.Трибеля. - К. - Фенікс. Колобіг. 2012. - 368 с.

6. Основи управління продукційним процесом польових культур: монографія / В. В. Кириченко. - Х.: ФОП Бровін В. О., 2016. - 712 с.

7. Жученко А. А. Возможности создания сортов и гибридов растений с учетом изменения климата // Стратегия адаптивной селекции полевых культур в связи с глобальными изменениями климата. Саратов, 2004. С. 10-16.

8. Шубравська О. Інноваційний розвиток аграрного сектора економіки: теоретико-методологічний аспект // Економіка України. - 2012. - № 1. - C.27-35.

\section{References}

1. Kropyvko V. Food safety of the country: the status and prospects / Valentyna Kropyvko // Proceedings of the Internet-Conference. October 20-21, 2011. Ternopil Institute of Agroindustrial Production - section 5. Economics. [Electronic resource]. Access at: http://www.conftiapv.at.ua/publ/konf_20_2 1_zhovtnja_2011_r/ sekcija_5_ekonomichni_nauki I.../ 23-1-0-1123 [in Ukrainian]

2. Tymchuk V.M. Problematic issues of transfer of technological innovations in agribusiness. Visnyk Ahrarnoi Nauky. No. 2, 2013. - P.23-25. [in Ukrainian]

3. Matiushenko I.Yu. Technological competitiveness of Ukraine during the new industrial revolution and development of convergent technologies. Problemy Ekonomiky. 2016. No. 1. P. 108-120. [in Ukrainian]

4. State Statistics Service of Ukraine. Official web-site. [Electronic resource]. Access at: http://www.ukrstat.gov.ua

5. Trybel S.O., Retman S.V., Borzykh O.I., Stryhun O.O. Strategic crops. Ed. by S.O. Trybel.- K. - Feniks. Kolobih 2012. - 368 p. [in Ukrainian]

6 . Basics of management of productional process of field crops: monograph / V.V. Kyrychenko. - Kh.: Sole Proprietor Brovin V.O., 2016. - 712 p. [in Ukrainian]

7. Zhugchenko A.A. Possibilities for creating plant varieties and hybrids with due account for climate changes // Strategy of adaptive breeding of field crops in the face of the global climate changes. Saratov, 2004. 10-16 p. [in Russian]

8. Shubravska O. Innovative development of the agrarian sector of economics: theoretical and methodological aspect // Ekonomika Ukrainy. - 2012. - No 1. - P.27-35. [in Ukrainian]

\section{Аннотация}

\section{Методологические подходы оценки зон трансфера кукурузы на зерно по показателю урожайности}

\section{В.М. Тымчук, Н.Ю. Егорова, Є.С. Бондаренко, Л.С. Осипова, С.Ф. Халин}

В качестве специфических зон трансфера кукурузы на зерно анализировали 25 областей и уровень по Украине. Анализ проводили по показателю урожайности за 2000 - 2016 гг. Для более системного учета зональных особенностей анализировали средний уровень $(\bar{x})$, а также градации минимальных (min) и максимальных (max) показателей в абсолютном, и сравнительном к Украине форматам. По коэфрфициенту регрессии всеі области характеризовалисья положительным значением в пределахх 0,030,58. Для более системного учета зональных особенностей анализировали средний $(\bar{x})$, минимальный (min) и максимальный (max) уровень показателей в абсолютном и сравнительно к Украине форматах. 
Дополнительно анализировали статистические и регрессионные коэффициенты як индикаторы уровня и характера имеющихся процессов. По каждой из градаций за счет ранжирования выделяли типичные пулы областей с формализованной типичностью по технологическому обеспечению и реализации генетического потенциалу продуктивности (РГПП). По точности апроксимации (R2) на удовлетворительном уровне $(0,8)$ выделялись АРК*, Волынская, Ивано-Франковская, Ровенская, Сумская, Тернопольская и Херсонская области, в которых в ближней перспективе можно ожидать роста урожайности кукурузы на зерно. Формализовано доля сумы всех градаций урожайности кукурузы на зерно $\leq 5,0$ т/га составляет- 66,6\% и 25,0 т/га 33,4\%. По показателю урожайности ведущий сегмент (76\%) сформировали 12 областей (48\%) с коэффрициентом вариации V\% - 20\% и 7 областей (28\%) V\% - 30\%. Проведенный анализ выделил актуальность зональной специализации, а также разработки и внедрения системы поправочных коэффициентов для достижения репрезентативного и одно форматного корректного уровня сравнения зон трансферу. При этом показатель урожайности рассматривается как индикатор необходимости обоснованной корректировки или разработки зональной системы технологического обеспечения производства кукурузы на зерно.

Ключевые слова: кукуруза на зерно, зоны трансфера, урожайность, вариация.

\section{Abstract}

\section{Methodological approaches to assessment of transfer zones of grain corn by yield}

\section{V.M. Tymchuk, N.Yu. Yehorova, Ye.S. Bondarenko, L.S. Osipova, S.F. Halin}

25 regions and the Ukraine level were analyzed as specific zones for the transfer of corn, The analysis was carried of the corn yield during 2000-2016. All regions were characterized by a positive regression coefficient within the range of 0.03-0.58. The average $(x)^{-}$, minimum ( $\mathrm{min}$ ) and maximal ( $\max$ ) yield gradations were analyzed in absolute and comparative formats. Were shown zonal features. The statistical and regression coefficients were analyzed as indicators of the level and nature of existing processes. Were distinguished typical pules areas with a formalized type of technological support and the implementation of the genetic potencial of productivity (RGPP). It is expected increase corn yieldin ARC *, Volyn, Ivano-Frankivsk, Rivne, Sumy, Ternopil and Kherson regions in the near future with the satisfactory approximation $(\mathrm{R} 2=0,8)$. Formalized part of of yield gradation $\leq 5.0 \mathrm{t} / \mathrm{ha}$ is $-66.6 \%$ and $\geq 5.0 \mathrm{t} /$ ha $33.4 \%$. The leading segment $(76 \%)$ were formed 12 regions (48\%) with a coefficient of variation $\mathrm{V} \%-20 \%$ and 7 regions $(28 \%)$ with $\mathrm{V} \%-30 \%$. The analysis has highlighted the relevance of zonal specialization and the development and implementation of a correction factor system to achieve a representative and correct level of comparison of transfer zones. The yield is considered as an indicator of the reasonable adjustment or development of a zonal system of technological support for the production of corn.

Keywords: corn, transfer zones, yield, variation.

\section{Бібліографічне посилання/ Bibliography citation: Harvard}

Tymchuk, V., Yehorova, N., Bondarenko, Ye., Osipova and Halin, S. (2019). Methodological approaches to assessment of transfer zones of grain corn by yield. Engineering of nature management, (3(13), pp. 43 - 50.

Подано до редакції / Received: 20.02.2019 